\title{
Mixture of vitamin C, hesperidin and piperidol exposure in pregnancy: maternal-fetal repercussions
}

\author{
Gustavo Tadeu Volpato ${ }^{1}$, Débora Cristina Damasceno ${ }^{1 *}$, Márcia Regina F. Miranda ${ }^{1}$, \\ Daher Sabbag Filho', Iracema de Mattos Paranhos Calderon', Marilza Vieira Cunha Rudge ${ }^{1}$
}

${ }^{1}$ Department of Gynecology and Obstetrics, Laboratory of Experimental Research of Gynecology and Obstetrics, School of Medicine of Botucatu - São Paulo State University (Unesp), ${ }^{2}$ Ambulatory of Clinical Genetic, Department of Pediatrics, School of Medicine of Marilia - FAMEMA, São Paulo

${ }^{*}$ Correspondence:

D. C. Damasceno

Departamento de Ginecologia e

Obstetrícia

Faculdade de Medicina de Botucatu UNESP

Distrito de Rubião Júnior, s/n

18618-000 - Botucatu, SP - Brazil

E-mail: damasceno@fmb.unesp.br
To evaluate the reproductive performance and the development of their offspring on rat pregnancy, Wistar pregnant rats were gavaged with $0 \mathrm{mg} / \mathrm{kg}$ wb/day (control group, $n=20$ ) and $166.5 \mathrm{mg} / \mathrm{kg} /$ day of a mixture of vitamin $C$, hesperidin and piperidol (experimental group, $n=20$ ) during the organogenic period (from day 5 to 14 of pregnancy; positive vaginal smear $=$ day 0). The female rats were killed on day 21 of pregnancy. The number of implantations, resorptions (dead embryos), and liveldead fetuses were counted for the analysis of the postimplantation loss rates. There was neither alteration in maternal reproductive performance, but it was verified an increase of the number of fetuses presenting dilated urether, hydronephrosis, and reduced ossification of skull due to the treatment of female rats with a mixture of vitamin $C$, hesperidin and piperidol, these abnormalities were considered transitory and may not interfere on offspring development. It was not verified other type of major malformation neither the appearance of fetuses presenting atrophy of upper limbs that it could be associated to use of this drug.
Uniterms

- Vitamin C

- Hesperidin and piperidol mixture

- Pregnancy

- Maternal repercussions

- Rats

\section{INTRODUCTION}

To evaluate real effect of a certain toxicant chemical agent in a pregnant woman, we should verify if the kinetic process in this organism is modified and consider the maternal-placental-fetal unit. Although a placental membrane exists between mother and fetus, this function is limited, because it depends on the physical characteristics of the substance transferred. These substances may cross the placenta by passive or facilitated diffusion, active transport, pinocytosis and breaks between the cells present in the placental membrane, causing deleterious effects on the embryo (Sadler, 2004). Elimination of drugs from the embryo or fetus is considered to be almost entirely dependent on the mothers. There is a low capacity of metabolizing of drugs in the fetal liver and an immaturity of the renal excretion. The role of the fetal kidney as a route of drug elimination seems to be insignificant (Fouts, 1973).

Several drugs are used during the gestation to prevent the premature uterine contractions. A mixture of ascorbic acid (50 mg), hesperidin complex $(50 \mathrm{mg})$ and piperidolate chloridrate $(100 \mathrm{mg})$ is used as muscular 
relaxant with aim of avoiding abortion and premature birth (Okumura, Kim, 1965; Watanabe et al., 1966). Although clinical studies were done with a mixture of vitamin C, hesperidin and piperidol to prevent premature uterine contractions based on its anticholinergic effect, it has been suggested that certain antispasm drugs may produce malformations via their effect on the acetylcholine and choline levels in the fetus (Moore, Persaud, 2004).

A great number of experimental studies have indicated that prenatal administration of hundreds of drugs can result in fetal death, malformations, growth suppression, and postnatal structural and functional developmental anomalies. The route of chemical exposure, selection and care of the experimental animals, environmental variables (caging, diet, temperature, and humidity), careful selection of dose levels and interpretation of results are important factors considered in toxicity testing (WHO, 2004).

At the Ambulatory of Clinical Genetic, School of Medicine of Marilia, São Paulo, Brazil (FAMEMA), there were reports of the three women that ingested mixture of vitamin $\mathrm{C}$, hesperidin and piperidol during pregnancy, but exact gestational period is unclear, and their offspring presented atrophy of upper limbs. Considering doubt about involvement of the mixture of vitamin $\mathrm{C}$, hesperidin and piperidol in occurrence of malformations, the present study was conducted to evaluate the reproductive performance and incidence of fetal malformations of rats treated with this mixture.

\section{MATERIAL AND METHODS}

\section{Animals}

Wistar female and male albino rats $(200 \pm 20 \mathrm{~g})$ were kept in a controlled room $\left(22 \pm 3{ }^{\circ} \mathrm{C}\right)$ with a $12 / 12 \mathrm{~h} \mathrm{light/}$ dark cycle. Animals had free access to food pellets (Purina ${ }^{\circledR}$ rat chow, Paulinia, São Paulo State, Brazil) and tap water ad libitum. All experimental procedures involving animals were approved by the ethical animal committee of the School of Medicine of Botucatu, São Paulo, Brazil.

\section{Drugs}

The control group received $0 \mathrm{mg} / \mathrm{kg}$ of the mixture of vitamin $\mathrm{C}$, hesperidin and piperidol. Two tablets of the mixture of vitamin C, hesperidin and piperidol $(166.5 \mathrm{mg} / \mathrm{kg})$ diluted into distilled water were administered to experimental group $(\mathrm{n}=20)$. The administered dose was five times higher than that used for human (the dose daily ingested by a woman weighing $60 \mathrm{~kg}$ is approximately $33.5 \mathrm{mg} / \mathrm{kg}$ ). The rat dose chosen was higher than that in woman treatment because of the sensibility difference among species (Lemonica, 2004).

\section{Experimental procedure}

Virgin female rats were mated overnight with adult Wistar male rats of the same strain. The morning spermpositive vaginal smears were detected and day 0 of gestation was considered. The mated rats were divided at random into two groups: $\mathrm{G} 1=$ control (distilled water), and $\mathrm{G} 2=$ treated with mixture of vitamin $\mathrm{C}$, hesperidin and piperidol. Each group received daily the treatment by gavage during the organogenic period of days 5-14 of pregnancy. Maternal weight gain was measured at morning (9:00 A.M.) of the days $0,7,14$ and 21 of pregnancy. All pregnant animals were killed on GD21 for evaluation of the number of implantation, resorption (dead embryo) and live fetuses were counted. The rate of postimplantation loss was calculated as: (Number of Implantation - Number of live fetuses)/ (Number of Implantation) $\mathrm{x} 100$. The fetuses and their placentas were dissected from the uterus, inspected for gross morphologic abnormality and weighed. After weighing, the fetuses were classified as small (SPA), appropriate (APA) and large (LPA) for pregnancy age compared to fetal body weight mean of the control group. The placental index was calculated as: Placental Weight/Fetal Corporal Weight (Calderon et al., 1992). The non-observed embryonic implantation was stained with Salewski method (Salewski, 1964). Fetuses were also evaluated in a microscope with respect to incidence of external malformation and anomaly. After external analysis of the fetuses, half the fetuses were fixed in Bouin's fluid and serial sections were prepared as described by Wilson (1965) for visceral examination. The remaining fetuses were prepared for examination of the skeletons by the staining procedure of Staples and Schnell (1964). The malformation term was considered when an incompatible structural abnormality with the survival was founded and anomaly term when an alteration of the normal process of the development was observed, but there was no alteration on the general or specific function nor on the individual development (Wilson, 1965; Traballi et al., 2000).

\section{Statistical analysis}

Results are presented as mean \pm standard deviation (SD). Data were analyzed by one-way ANOVA, Chisquare and Goodman tests (Zar, 1999). Differences were considered statistically significant when $\mathrm{P}<0.05$.

\section{RESULTS}

\section{Reproductive performance}

At day 21 of pregnancy, the reproductive perfor- 
mance of the dams treated with mixture of vitamin C, hesperidin and piperidol during organogenic period was similar to that of the control group (Table I). There was no significant difference in the mean number of implantation sites. There was a mean of $11.4 \pm 3.5$ live fetuses in the control group, and $10.9 \pm 2.8$ in the treated group. The rate of loss of the embryos after implantation was not different compared to the control (Table I).

TABLE I - Reproductive performance of Wistar rats treated with a mixture of vitamin $\mathrm{C}$, hesperidin and piperidol during the organogenic period.

\begin{tabular}{lcc}
\hline Groups & Control & Treated \\
\hline No females & 20 & 20 \\
$\quad$ mated & 20 & 20 \\
$\quad$ pregnant & 0 & 0 \\
Number of total resorptions & $13.1 \pm 1.5$ & $13.8 \pm 2.4$ \\
Number of corpora-lutea & $12.2 \pm 2.5$ & $11.9 \pm 2.2$ \\
Number of implantation & $11.4 \pm 3.5$ & $10.9 \pm 2.8$ \\
Number of live fetuses & 7.0 & 7.9 \\
Mean postimplantation loss $(\%)$ & $80.2 \pm 24.3$ & $77.8 \pm 19.5$ \\
Maternal weight gain $(\mathrm{g})$ &
\end{tabular}

No difference $(p>0.05)$ compared to the control group

\section{Fetal and Placental Analysis}

Exposure to the mixture of vitamin $\mathrm{C}$, hesperidin and piperidol did not significantly alter fetal weight throughout the pregnancy (Figure 1), neither the fetal

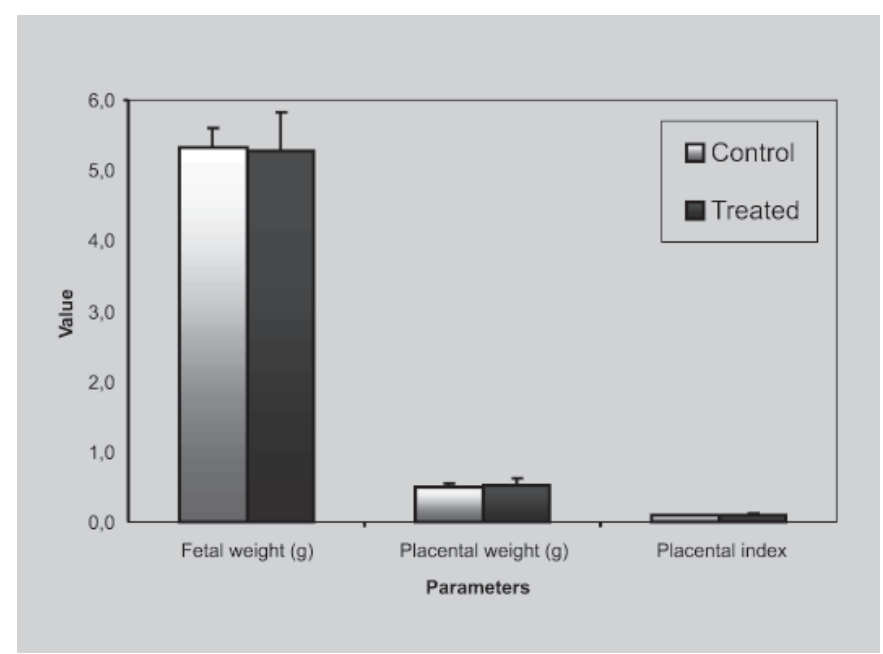

FIGURE 1 - Fetal weight, placental index and weight of Wistar rats treated with a mixture of vitamin $\mathrm{C}$, hesperidin and piperidol during the organogenic period. (No difference $(p>0.05)$ compared to the control group). classification for pregnancy age (Figure 2). The placental weight and index showed no statistical difference compared to the control group (Figure 1).

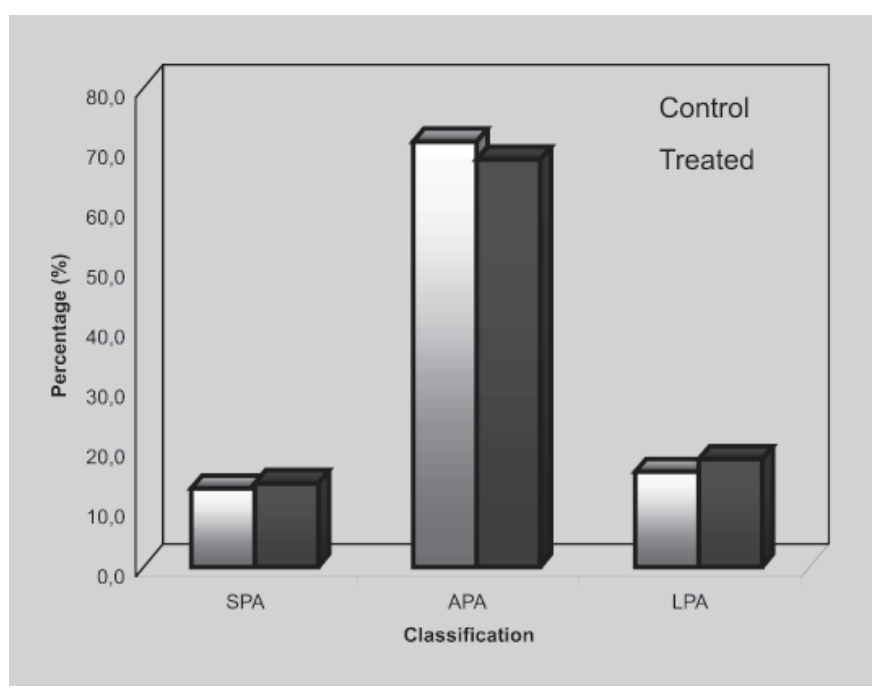

FIGURE 2 - Incidence (percentage) of fetuses classified as small (SPA), appropriate (APA) and large (LPA) for the pregnancy age of Wistar rats treated with a mixture of vitamin $\mathrm{C}$, hesperidin and piperidol during the organogenic period. (No difference $(p>0.05)$ compared to the control group).

\section{Incidence of fetal malformation and anomaly}

The analysis of the incidence of external malformation and anomaly was accomplished in 448 fetuses. Two of the 20 litters (12 fetuses) of the control group and two of the 20 litters (13 fetuses) of the mixture of vitamin $\mathrm{C}$, hesperidin and piperidol group were discarded because the fetuses were dissolved during skeletal preparation that did not permit fetal analysis (Table II). Female rats treated with the mixture presented higher occurrence of fetal visceral malformation, and also skeletal and visceral anomalies compared to the control group. The rate of reduced ossification of skull, a type of skeletal anomaly was increased in fetuses of rats treated with mixture compared to the control group. The visceral malformation observed was hydronephrosis, the skeletal anomaly presented was reduced ossification, and the visceral anomaly verified was enlarged urether (hydrourether) (Table II).

\section{DISCUSSION}

Although safety evaluation of exposure to chemicals is generally based on studies of single compounds, humans are exposed to combination of chemicals. The difficulties of 
TABLE II - Incidence of fetal malformation and anomaly of Wistar rats treated with a mixture of vitamin C, hesperidin and piperidol during organogenic period

\begin{tabular}{|c|c|c|}
\hline Groups & Control & Treated \\
\hline \multicolumn{3}{|l|}{ External Malformation } \\
\hline Affected Litters & $0 / 20$ & $2 / 20$ \\
\hline Affected Fetuses & $0 / 227$ & $2 / 221$ \\
\hline Macroglossia & $0 / 227$ & $2 / 221$ \\
\hline \multicolumn{3}{|l|}{ Skeletal Anomaly } \\
\hline Affected Litters & $14 / 18$ & $16 / 18$ \\
\hline Affected Fetuses & $28 / 104$ & $51 / 103 *$ \\
\hline $14^{\text {th }} \mathrm{rib}$ & $10 / 104$ & $14 / 103$ \\
\hline Butterfly vertebrae & $1 / 104$ & $4 / 103$ \\
\hline Cleaved vertebrae & $7 / 104$ & $3 / 103$ \\
\hline Rudimentar sternebrae & $4 / 104$ & $2 / 103$ \\
\hline Inshaped sternebrae & $9 / 104$ & $15 / 103$ \\
\hline Supranumerary sternebrae & $0 / 104$ & $2 / 103$ \\
\hline Reduced ossification of skull & $9 / 104$ & $23 / 103 *$ \\
\hline \multicolumn{3}{|l|}{ Skeletal Malformation } \\
\hline Affected Litters & $5 / 18$ & $3 / 18$ \\
\hline Affected Fetuses & $6 / 104$ & $4 / 103$ \\
\hline Cleft palate & $6 / 104$ & $4 / 103$ \\
\hline \multicolumn{3}{|l|}{ Visceral Anomaly } \\
\hline Affected Litters & $4 / 20$ & $19 / 20 *$ \\
\hline Affected Fetuses & $29 / 111$ & $45 / 105^{*}$ \\
\hline Enlarged urether & $29 / 111$ & $44 / 105^{*}$ \\
\hline Hyperplasic bladder & $0 / 111$ & $1 / 105$ \\
\hline \multicolumn{3}{|l|}{ Visceral Malformation } \\
\hline Affected Litters & $2 / 20$ & $10 / 20 *$ \\
\hline Affected Fetuses & $3 / 111$ & $12 / 105 *$ \\
\hline Hydronephrosis & $3 / 111$ & $12 / 105 *$ \\
\hline
\end{tabular}

* Difference $(p<0.05)$ compared to the control group (Goodman test)

toxicity studies with mixtures are broadly acknowledged and a source of continued concern. The extreme complexity of mixture toxicity has suggested new research methodologies to study interactive effects (taking into account limited resources), including statistical designs and mathematical modeling of toxicokinetics and toxicodynamics. Complex mixtures likely produce more unexpected results than individual chemical substances. Mixtures are composed of various substances, exposure to which can be expected to be associated with different toxicities. The constituents of a mixture sometimes combine chemically to produce new compounds with different toxicities. Additionally, the presence of some mixtures might mask, dilute or increase toxicity of other materials. Such phenomena, referred to as interactions, can amplify or reduce anticipated results. Another consideration is that different doses of separate materials might increase the bioavailability of materials that are otherwise non-toxic at the doses present in the mixture. The potential adverse impacts of chemicals are dependent on a number of factors including levels and duration of exposure, the mechanism of action and interactions among chemicals in a mixture. It should be noted that hazard and risk assessment of chemicals performed by regulatory agencies have primarily focused on the toxicities of individual compounds and to a remarkably diminished extent to mixtures (WHO, 2004).

Literature presents no data about reproductive performance and fetal repercussions after mixture of vitamin $C$, hesperidin and piperidol treatment. The present results showed that this mixture administration cause no maternal toxicity, because there was no difference in the mean corporal weight gain of the female rats of the different groups. There is no published evidence about fetal abnormalities caused by of vitamin $\mathrm{C}$ and hesperidin administered by oral gavage to rats during organogenic period. In this study, a mixture of vitamin $\mathrm{C}$, hesperidin and piperidol treatment caused no embryonic death and it did not influence placental weight. The weight classification of the fetuses for pregnancy age was similar between control and experimental groups, showing that the drug mixture caused no influence on fetal weight. Nevertheless, this study revealed that a mixture of vitamin $\mathrm{C}$, hesperidin and piperidol interfered in the development of the urinary system, because it was capable to induce enlarged urether (41.9\% of the fetuses) and hydronephrosis (11.4\% of fetuses). The grave dilatation of the urether is recognized easily because the extensive urether are molded in "S" or twisted, completely transparent and, then, easily identifiable, as observed in this study. Besides, the enlarged urether may or not to be associated to the congenital hydronephrosis and any pelvic alteration, which may be considered transitory in rodents (Taylor, 1986). Damasceno et al. (2002) verified that 10 to $20 \%$ of the fetuses from female control rats also presented this type of visceral anomaly. The reduced ossification of skull in fetuses of rats treated with mixture might be considered transitory. Nishimura and Tanimura (1976) reported that a girl with severe skull defect and growth retardation due to her mother's ingestion of drug pregnancy has later shown great improvement in physical growth and her mental and social development are normal at age of nine.

In spite of the increase of the number of fetuses presenting dilated urether, hydronephrosis, and reduced ossification of skull due to the treatment of female rats with a mixture of vitamin $\mathrm{C}$, hesperidin and piperidol, these abnormalities were considered transitory and may not inter- 
fere on offspring development. It was verified neither other type of major malformations nor the appearance of fetuses presenting atrophy of upper limbs that it could be associated to use of this drug. Thus, considering doubt about involvement of this mixture in occurrence of malformations on offspring from women that ingested this drug during the gestational period, this study showed that rodents exposed to the drugs present no alteration on the development of the limbs during the organogenic period in the experimental conditions carried out.

\section{RESUMO}

\section{Exposição à mistura de vitamina $\mathrm{C}$, hesperidina $\mathrm{e}$ piperidol durante a gravidez: repercussões materno-fetais}

Para avaliar a performance reprodutiva de ratas e o desenvolvimento de seus filhotes, ratas Wistar prenhes foram tratadas por gavage com $0 \mathrm{mg} / \mathrm{kg}$ peso corpóreo/dia (grupo controle, $n=20$ ) e 166,5 mg/kg/dia de mistura de vitamina $C$, hesperidina e piperidol (grupo experimental, $n=20$ ) durante o periodo organogênico (do $5^{\circ}$ ao $14^{\circ}$ dia de prenhez, considerando esfregaço vaginal positivo $=$ dia 1). As ratas foram mortas no $21^{\circ}$ dia de prenhez. O número de implantações, reabsorções (morte embrionária) e os fetos vivos e mortos foram contados para avaliação da taxa de perda pós-implantação. Não houve alteração na performance reprodutiva materna, mas foi verificado aumento no número de fetos com uretér dilatado, hidronefrose e ossificação reduzida do crânio devido ao tratamento das ratas com a mistura de vitamina $C$, hesperidina e piperidol. Essas anormalidades foram consideradas transitórias e não interfeririam no desenvolvimento dos filhotes. Não foram observados outros tipos de malformações amiores e os fetos também apresentaram atrofia dos membros superiores que pudesse estar relacionado ao uso desta mistura.

UNITERMOS: Mistura de vitamina C. hesperidina e piperidol. Gravidez. Repercussões maternas. Ratos.

\section{REFERENCES}

CALDERON, I.M.P.; RUDGE, M.V.C.; BRASIL, M.A.M.; RAMOS, M.D. Diabete e gravidez experimental em ratas I. Indução do diabete, obtenção e evolução da prenhez. Acta Cir. Bras., São Paulo, v. 7, p. 142-146, 1992.
DAMASCENO, D.C.; VOLPATO, G.T.; PERSON, O.C.; TOSHIDA, A.; CALDERON, I.M.P.; RUDGE, M.V.C. Efeito do ácido acetilsalicílico na performance reprodutiva e na prole de ratas Wistar. Rev. Assoc. Med. Bras., São Paulo, v. 48, p. 312-316, 2002.

FOUTS, J.R. Some studies on hepatic microssomal drugmetabolizing enzymes environment interactions. Drug Metabolism. Dispos., Bethesda, v. 1, p. 380-385, 1973.

LEMONICA, I.P: Teratogênese experimental e sua aplicação em humanos. In: SANSEVERINO, M.T.V., SPRITZER, D.T., SCHÜLER-FACCINI, L. Manual de Teratogênese. Porto Alegre: Editora da Universidade, 2004. cap. 2, p. 19-40.

MOORE, K.L.; PERSAUD, T.V.N. Defeitos congênitos humanos. In: .Embriologia Clínica. 7. ed. Rio de Janeiro: Elsevier, 2004. p. 173-206.

NISHIMURA, H.; TANIMURA, T. Clinical aspects of the teratogenicity of drugs. Amsterdam: Excerpta Medica, 1976. p. 105.

OKUMURA, H.; KIM, S. Clinical effect of Dactil-OB as an uterine relaxant. Sanfujinka No Jissai- Pract. Gynecol. Obstet., Tokyo, v. 14, p. 768-771, 1965.

SADLER, T.W. Do terceiro mês ao nascimento: o feto e a placenta. In: Langman embriologia médica. 9. ed. Rio de Janeiro: Guanabara-Koogan, 2004. p. 79-98.

SALEWSKI, E. Farbemethode zum markroskopishen nachweis von implantatconsstellen na uterus der ratter naunyn schmuderbergs. Arch. Pharm., Weinheim, v. 247 , p. $367,1964$.

STAPLES, R.E.; SCHNELL, V.L. Refinements in rapid clearing technic in the $\mathrm{KOH}$-alizarin red $\mathrm{S}$ method for fetal bone. Stain Technol., Baltimore, v. 39, p. 61-63, 1964.

TAYLOR, P. Practical teratology. London: Academic Press, 1986. p. 48-57.

TRABALLI, A.L.M.; SILVA, C.F.S.; LOPES, D.L.; DAMASCENO, D.C.; SABBAG, D. Malformações congênitas: definições, histórico, riscos teratogênicos e programa de investigação de malformações congênitas (P.I.M.C.). Acta Acadêmica, Marília, v. 2, p. 8-10, 2000. 
WATANABE, M.; KISANUKI, K.; KAWASAKI, S.; ISHIKAWA, K. Clinical use of Dactil-OB for miscarriage and premature delivery. Sanfujinka No Jissai-Pract. Gynecol. Obstet., Tokyo, v. 15, p. 362-364, 1966.

WORLD HEALTH ORGANIZATION. Hazard Identification. IPCS Training. Disponível em: $<$ http:// www.who.int> Acesso em: 21 ago. 2004.
WILSON, J.G. Methods for administering agents and detecting malformations in experimental animal. In: WILSON, J.G.; WARKANY, J. Teratology: principles and techniques. Chicago: University of Chicago Press, 1965. p. 47-74.

ZAR, J.H. Biostatistical analisys. New Jersey: Prentice-Hall, 1999. $929 \mathrm{p}$.

Recebido para publicação em 19 de outubro de 2004 Aceito para publicação em 30 de janeiro de 2006 